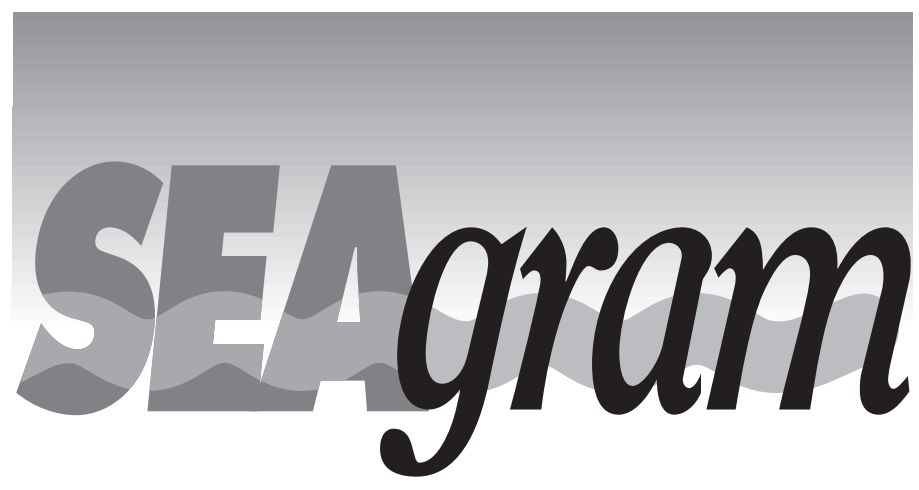

ALASKA SEA GRANT

MARINE ADVISORY PROGRAM

Single Copies Free

No. 301989 (2nd Printing 1995)

\title{
Seafood Shelf Life as a Function of Temperature
}

\section{Introduction}

Seafood consumption in the United States has increased dramatically in the past 10 years. Consumers have become more aware of the benefits of eating fish and of having fish of high quality. While consumption has increased, so have imports of very high quality salmon and ocean white fish. The American fisheries industry needs to meet this competition directly by improving quality and by marketing more fresh product.

The seafood-consuming public in the United States prefers fresh fish to frozen. In a recent study done for the Alaska Seafood Marketing Institute, 70\% of the people interviewed said they prefer fresh rather than frozen fish. Less than $20 \%$ said they prefer frozen. The remainder had no preference. The public perception is that fresh fish is better than frozen (Ref. 1). Most consumers cannot tell the difference between good frozen seafood and fresh seafood, yet it is a fact that good frozen fish is better than poor fresh fish.

Both fresh and frozen fish are perishable. The consumer recognizes quality; therefore, it behooves the industry to market the highest quality product as quickly as possible. In general that strategy will yield the greatest economic return to the industry. It is to the industry's advantage to make every effort to extend the shelf life of all seafood; this will provide the longest possible time to market the product. Maximizing shelf life will get more fresh product on the market.

\section{Shelf Life}

Shelf life of food is defined as the maximum length of time a given product is fit for human consumption. For fish, shelf life is the time from when it is taken from the water until it is no longer fit to eat. In marketing, the shelf life of fresh and frozen fish is a very important consideration. Knowing the remaining shelf life allows the processor and retailer to plan the length of time a product can be held, allowing control of their market. Adding one or two days to the shelf life allows the market to get top dollar and assure repeat sales.

Temperature and handling practices are the most important factors in determining the shelf life of all species of fish. If the fish product is handled carefully, the temperature at which it is held controls its useful life. Temperature will control 
Equivalent days on ice computations were carried out to three places for mathematical accuracy only. Because of biological variability within a species, numbers are only meaningful to one place past decimal point.
Table 1: Relative rates of spoilage and loss of equivalent days on ice for different temperatures and times.

$\begin{array}{rcc}{ }^{\circ} \mathbf{C} & \begin{array}{c}\text { Temp } \\ { }^{\circ} \mathbf{F}\end{array} & \begin{array}{c}\text { Relative rate } \\ \text { of spoilage }=\boldsymbol{r}\end{array} \\ -2 & 28.4 & 0.64 \\ 0 & 32.0 & 1.00 \\ 2 & 35.6 & \mathrm{I} .44 \\ 4 & 39.2 & 1.96 \\ 6 & 42.8 & 2.56 \\ 8 & 46.4 & 3.24 \\ 10 & 50.0 & 4.00 \\ 12 & 53.6 & 4.84 \\ 15 & 59.0 & 6.25\end{array}$

\begin{tabular}{lccccccc}
\multicolumn{8}{c}{ Equivalent days on ice with time } \\
\hline $\mathbf{4} \mathbf{~ h r}$ & $\mathbf{8} \mathbf{~ h r}$ & $\mathbf{1 2} \mathbf{~ h r}$ & $\mathbf{1 8} \mathbf{~ h r}$ & $\mathbf{2 4} \mathbf{~ h r}$ & $\mathbf{3 6} \mathbf{~ h r}$ & $\mathbf{4 8} \mathbf{~ h r}$ & $\mathbf{7 2} \mathbf{~ h r}$ \\
0.11 & 0.21 & 0.32 & 0.48 & 0.64 & 0.96 & 1.28 & 1.92 \\
0.16 & 0.33 & 0.50 & 0.75 & 1.00 & 1.50 & 2.00 & 3.00 \\
0.24 & 0.48 & 0.72 & 1.08 & 1.44 & 2.16 & 2.88 & 4.32 \\
0.33 & 0.65 & 0.98 & 1.47 & 1.96 & 2.94 & 3.92 & 5.88 \\
0.43 & 0.85 & 1.28 & 1.92 & 2.56 & 3.84 & 5.12 & 7.68 \\
0.54 & 1.08 & 1.62 & 2.43 & 3.24 & 4.86 & 6.48 & 9.72 \\
0.66 & 1.33 & 2.00 & 3.00 & 4.00 & 6.00 & 8.00 & 12.00 \\
0.81 & 1.61 & 2.42 & 3.63 & 4.84 & 7.26 & 9.68 & 14.52 \\
1.04 & 2.08 & 3.12 & 4.69 & 6.25 & 9.38 & 12.50 & 18.75
\end{tabular}

the rate of bacterial spoilage and enzyme breakdown. An indisputable fact is that the higher the temperature the faster fish spoil.

\section{Theory}

Years of research at CSIRO, Division of Food Research, Hobart, Australia, have led to the development of a simple formula that accurately predicts the growth rate of spoilage bacteria and deterioration rate of muscle food between temperatures of $-2^{\circ} \mathrm{C}$ and $20^{\circ} \mathrm{C}\left(28.4^{\circ} \mathrm{F}\right.$ and $\left.68^{\circ} \mathrm{F}\right)$ (Ref. 2,3,4). The formula also holds true for biochemical changes at temperatures between $0^{\circ} \mathrm{C}$ and $20^{\circ} \mathrm{C}\left(32^{\circ} \mathrm{F}\right.$ and $\left.68^{\circ} \mathrm{F}\right)$ (Ref. 5). The application of this rule to a large number of species of fish and its practical application to fish spoilage have been demonstrated (Ref. 6,7,8).

A simplified form of the relationship linking temperature and spoilage which calculates the rate of spoilage in relation to (or in comparison to) the rate at $0^{\circ} \mathrm{C}$ (melting ice) is $r=(0.1 t+1)$, where $r$ is the relative rate of spoilage and $t$ is temperature (in ${ }^{\circ} \mathrm{C}$ ). When fish is well chilled and has a temperature of $0^{\circ} \mathrm{C}$, then $\sqrt{r}$ is 1 . If the fish is at $4^{\circ} \mathrm{C}\left(39.2^{\circ} \mathrm{F}\right)$ and $t=4$, then

$$
\begin{aligned}
& r=(0.1 \times 4+1)^{2} \\
& r=1.4^{2} \\
& r=1.96, \text { i.e., } 2
\end{aligned}
$$

indicating that it is spoiling twice as fast at $4^{\circ} \mathrm{C}$ than it would at $0^{\circ} \mathrm{C}$. If the total shelf life of a species of fish held in ice from the time of catching is known, and the past holding temperature is known, the remaining shelf life can be calculated. Fishermen, processors, and retailers can estimate the days of shelf life remaining if the product has been handled carefully at all steps of the harvest, processing, and shipping chain.

\section{Application}

As an example of how the formula works, assume that sockeye salmon have been on a gillnetter for 18 hours and the average temperature has been $50^{\circ} \mathrm{F}\left(10^{\circ} \mathrm{C}\right)$ (conditions not unusual in Alaska). The fish are then transferred to an RSW tender and the temperature is lowered to $35.5^{\circ} \mathrm{F}\left(2^{\circ} \mathrm{C}\right)$ and delivered to the processor 36 hours later. Knowing the temperature history, we can compute the days of shelf 


\section{Figure 1. Equivalent days on ice at selected storage temperatures compared to actual storage times.}

To use the graph find the actual storage time on the bottom axis, and then trace up to the temperature and then across to the left vertical axis to read the equivalent days on ice.

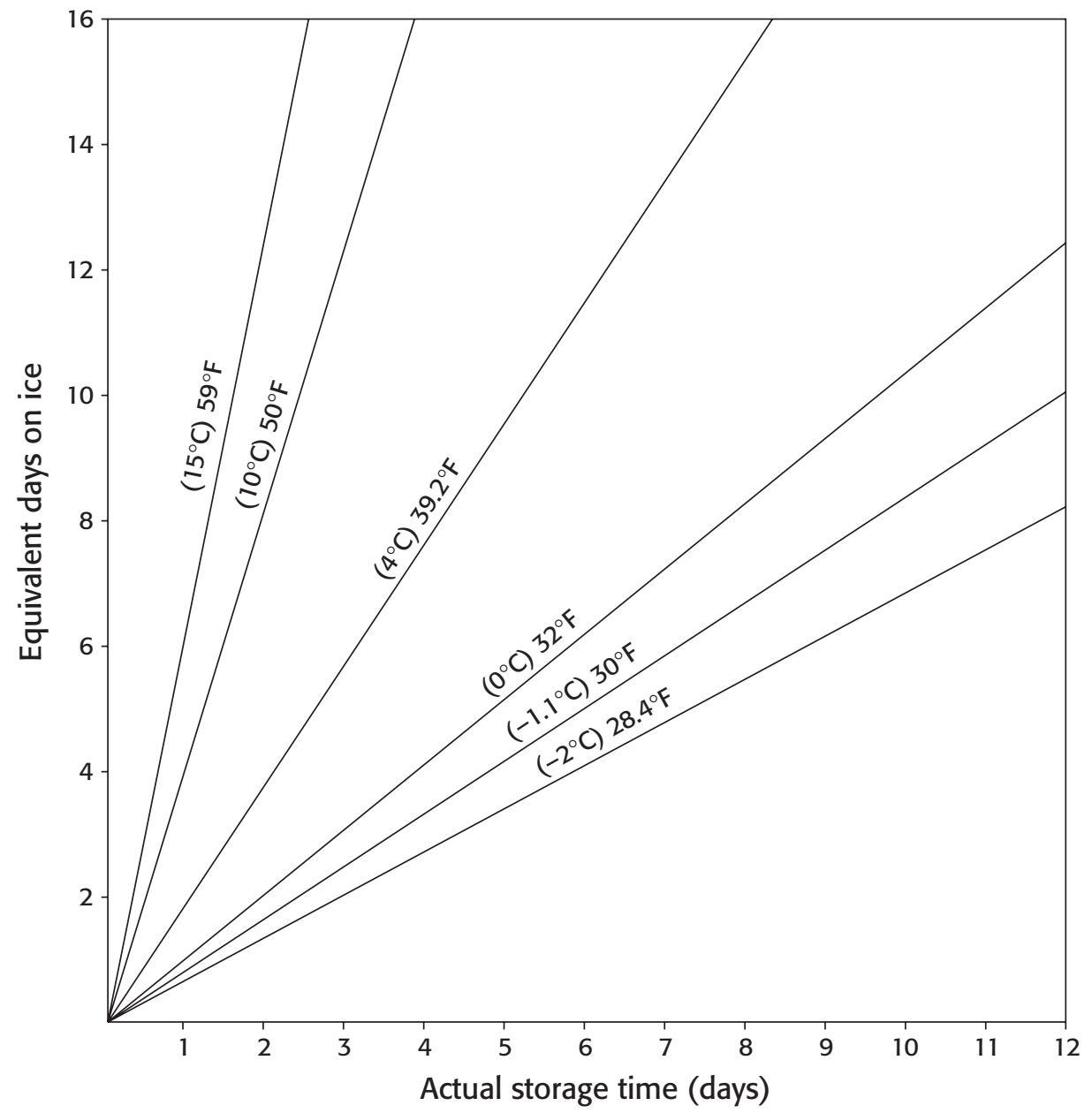

life or the "equivalent days on ice" used by the time the fish arrived at the plant. Fishing boat time:

$$
\begin{aligned}
\sqrt{r} & =(1+0.1 \times 10) \\
r & =(1+1)^{2}=2^{2} \\
r & =4
\end{aligned}
$$

To get the equivalent days on ice, multiply $r$ by the time the fish spent at the temperature, in this case 18 hours or .75 days, $4 \times 0.75=3$. Time on tender:

$$
\begin{aligned}
\sqrt{r} & =1+0.1 \times 2 \\
r & =(1+0.2)^{2}=1.2^{2} \\
r & =1.44 \text { (round off to } 1.4)
\end{aligned}
$$

Equivalent days on ice $=1.4 \times 1.5=2.1$. Because the equivalent days on ice are additive, the days of shelf life used are $3+2.1=5.1$. Under the best handling procedures in the commercial fishery, i.e., chilled to $32^{\circ} \mathrm{F}\left(0^{\circ} \mathrm{C}\right)$ immediately after catching, the average shelf life of sockeye salmon is 12 days. Therefore 6.9 days of 


\section{Table 2: The effect of delayed chilling on shelf life. Days remain- ing after holding fish at $50^{\circ} \mathrm{F}\left(10^{\circ} \mathrm{C}\right)$ for indicated time.}

${ }^{1}$ Assumes fish were chilled immediately, handled gently, and held under clean conditions at each step of harvesting, processing, shipping, and display.
Maximum shelf life'

\section{Species}

Halibut

Chum salmon

Sockeye salmon

Pacific cod

Silver salmon

ocean run

mature fish

King salmon

Sablefish

Pink salmon

Pollock

\section{Days}

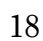

13

12

12

10

12

12

10

10

6

5

\begin{tabular}{rrrcc}
\multicolumn{5}{c}{ Days of remaining shelf life } \\
\hline $\mathbf{4 ~ h r}$ & $\mathbf{8} \mathbf{~ h r}$ & $\mathbf{1 2} \mathbf{~ h r}$ & $\mathbf{2 4} \mathbf{~ h r}$ & $\mathbf{4 8} \mathbf{~ h r}$ \\
17.3 & 16.6 & 16 & 14 & 10 \\
12.3 & 11.6 & 11 & 9 & 5 \\
11.3 & 10.6 & 10 & 8 & 9 \\
11.3 & 10.5 & 10 & 8 & 4 \\
& & & & \\
9.3 & 8.6 & 8 & 6 & 2 \\
11.3 & 10.6 & 10 & 8 & 4 \\
9.3 & 8.6 & 8 & 6 & 2 \\
9.3 & 8.6 & 8 & 6 & 2 \\
5.3 & 4.6 & 4 & 2 & 0 \\
4.3 & 3.6 & 3 & 1 & 0
\end{tabular}

shelf life remain at the time the fish reaches the plant. If processing takes 6 hours and the fish reaches a temperature of $15.6^{\circ} \mathrm{C}\left(60^{\circ} \mathrm{F}\right)$ the relative rate of spoilage is 6.5. The equivalent days on ice would be $6.5 \times 0.25=1.6$ days. Although the fish has been out of the water for only 2.5 days, it has already lost the equivalent of 6.7 days of shelf life, leaving only 5.3 days to get the product to and used by the consumer.

Table 1 gives the relative rate of spoilage at temperatures between $-2^{\circ} \mathrm{C}$ to $15^{\circ} \mathrm{C}\left(28.4\right.$ to $\left.59^{\circ} \mathrm{F}\right)$ over time up to 72 hours. To use the table, find the temperature of the product and read across to the time the product has been held at that temperature and read the equivalent days on ice or shelf life used. For example, if a fish has been held at $6^{\circ} \mathrm{C}\left(42.8^{\circ} \mathrm{F}\right)$ for 48 hours we find that 2 days is equal to just over 5 days on ice. Surely that is a sufficient reason to be concerned about any delay in chilling fish after catching.

A graphic method for determining equivalent days on ice is shown in Figure 1 for temperatures of $-2^{\circ} \mathrm{C}\left(28.4^{\circ} \mathrm{F}\right),-1.1^{\circ} \mathrm{C}\left(30^{\circ} \mathrm{F}\right), 0^{\circ}\left(32^{\circ} \mathrm{F}\right), 4^{\circ} \mathrm{C}\left(39.2^{\circ} \mathrm{F}\right), 10^{\circ} \mathrm{C}$ $\left(50^{\circ} \mathrm{F}\right)$, and $15^{\circ} \mathrm{C}\left(59^{\circ} \mathrm{F}\right)$. To use the graph find the actual storage time on the bottom axis, and trace up to the temperature and then across to the left vertical axis to read the equivalent days on ice. Note at temperatures below $0^{\circ} \mathrm{C}$ the growth rate of bacteria is significantly slowed. The rate of bacterial spoilage at $-2^{\circ} \mathrm{C}$ is only $64 \%$ of that at $0^{\circ} \mathrm{C}$. This shows the potential advantage of refrigerated sea water systems. Because fish will start to freeze at $-2^{\circ} \mathrm{C}$ we do not recommend holding temperatures below $-1.1^{\circ} \mathrm{C}\left(30^{\circ} \mathrm{F}\right)$ if roe quality is an important consideration.

More temperature lines can be added to Figure 1 using the above formula. Select the temperature desired, take the rate of spoilage given in Table 1, multiply by 2 or more days, plot the point on the graph, and draw a line from zero through the point. Note that at temperatures above $4^{\circ} \mathrm{C}$ the equivalent days on ice count up very fast.

For many species of fish taken off the coast of Alaska that are commonly handled through commercial channels, there are good estimates of total fresh shelf life. If we know the temperature history of a fish we can estimate the remaining shelf life of the product. 
Table 2 gives examples of shelf life remaining for different species held at $10^{\circ} \mathrm{C}$ $\left(50^{\circ} \mathrm{F}\right)$ from 4 to 48 hours. We can only estimate, because of biological variations within a species, size differences, and effect of different habitats and conditions. For example, small fish spoil faster than large fish of the same species. Table 2 shows the damaging effects of high temperatures. Note that pink salmon held at $50^{\circ} \mathrm{F}$ for 48 hours would not be fit for either the fresh or frozen market.

There are still too many fishermen, processors, and retailers who fail to see the need for rapid chilling and gentle handling of seafood. That attitude must change. In the long term, the fishermen, processors, and everyone else in the distribution chain will benefit economically from handling practices that extend the shelf life of the product.

\section{Acknowledgments}

I wish to thank Dr. Allan Bremner of the Commonwealth Scientific and Industrial Research Organisation (CSIRO), Hobart, Australia, for his valuable comments and suggestions which clarified the theoretical basis of this paper. I thank Professor John Liston, University of Washington, for his review and helpful comments. Thanks are also due to Jim Major, East Point Seafood; Cliff Phillips, E.C. Phillip \& Son; Bob Scott, Salamatof Seafoods; and Harold Thompson, Sitka Sound Seafoods, for their helpful comments. The responsibility for errors remains my own.

\section{References}

1. Evans Kraft Co. 1988. Report to the Alaska Seafood Marketing Institute on a Survey of Consumer Preferences in Seafood.

2. Olley, J. and D.A. Ratkowsky. 1973. Temperature Function Integration and Its Importance in the Storage and Distribution of Flesh Foods Above the Freezing Point. Journal of Food Technology in Australia 25(2):66-73.

3. Ratkowsky, D.A., J. Olley, T.A. McMeekin and A. Ball. 1982. Relationship Between Temperature and Growth Rate of Bacteria Cultures. Journal of Bacteriology 149(1):1-5.

4. Ratkowsky, D.A., R.K. Lowry, T.A. McMeekin, A.N. Stokes and R.E. Chandler. 1983. Model for Bacterial Culture Growth Rate Throughout the Entire Biokinetic Temperature Range. Journal of Bacteriology 154(3):1222-1226.

5. Otha, F. and T. Hirahara. 1977. Rate of Degradation of Nucleotides in Cold-Stored Carp Muscle. Kagoshima University Faculty of Fisheries Memoirs 26:97-102.

6. Bremner, A. 1984. Quality-An Attitude of Mind. In Australian Fishing Industry Today and Tomorrow. The Australian Maritime College, Launceston, Tasmania, Australia, 10-12 July 1984, pp. 244-269.

7. Bremner, H.A., J. Olley and A.M.A. Vail. 1987. Estimating Time-Temperature Effects by a Rapid Systematic Sensory Method. In Seafood Quality Determination. D.E. Kramer and J. Liston, eds., Elsevier, Amsterdam, pp. 413-436.

8. Ronsivalli, L.J. and S.E. Charm. 1975. Spoilage and Shelf Life Prediction of Refrigerated Fish. Marine Fisheries Review 37(4):32-34. 


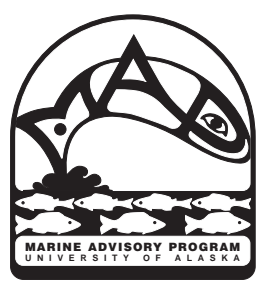

Alaska Sea Grant Marine Advisory Program Anchorage

Donald E. Kramer

Seafood Technology Specialist

Craig S. Wiese

Business Management Specialist

John P. Doyle

Professor of Fisheries

\section{Ray RaLonde}

Aquaculture Specialist

Marine Advisory Program

University of Alaska Fairbanks

2221 E. Northern Lights Blvd. \#110

Anchorage, Alaska 99508-4140

(907) 274-9691

Fax (907) 277-5242

\section{Bethel}

Gerri Hoffman Sumpter

Assistant Agent

UAF Kuskokwim Campus

P.O. Box 368

Bethel, Alaska 99559

(907) 543-4515

Fax (907) 543-4527

\section{Cordova}

Rick Steiner

Marine Advisory Agent

P.O. Box 830

Cordova, Alaska 99574

(907) 424-3446

Fax (907) 424-5246

\section{Dillingham}

\section{Terry Johnson}

Marine Advisory Agent

P.O. Box 1549

Dillingham, Alaska 99576

(907) 842-1265

Fax (907) 842-5692

\section{Homer}

\section{Douglas Coughenower}

Assistant Chairman

Marine Advisory Agent

4014 Lake Street, Suite 201B

Homer, Alaska 99603

(907) 235-5643

Fax (907) 235-6048
Kodiak

\section{Hank Pennington}

Marine Advisory Agent

Safety Specialist

(907) 486-1514

\section{Chuck Crapo}

Seafood Quality Specialist

(907) 486-1515

\section{Kate Wynne}

Marine Mammal Specialist

(907) 486-1517

Fishery Industrial Technology Center 900 Trident Way

Kodiak, Alaska 99615

(907) 486-1500

Fax (907) 486-1540

\section{Petersburg}

Brian Paust

Marine Advisory Agent

P.O. Box 1329

Petersburg, Alaska 99833

(907) 772-3381

Fax (907) 772-4431

\section{Seward}

(first Monday and Tuesday of each month)

\section{Douglas Coughenower}

Marine Advisory Agent

Seward Marine Center

P.O. Box 730

Seward, Alaska 99664

(907) 224-5261

Fax (907) 224-3392

\section{Sitka}

Dolly Garza

Marine Advisory Agent

1297 Seward Ave.

Sitka, Alaska 99835

(907) 747-3988

Fax (907) 747-1443

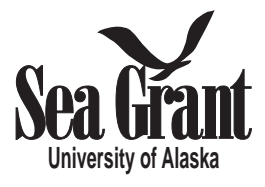

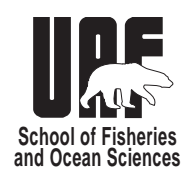

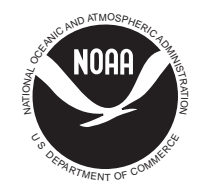

\author{
Alaska Sea Grant College Program \\ University of Alaska Fairbanks \\ P.O. Box 755040 \\ Fairbanks, AK 99775-5040 \\ (907) 474-6707 \\ Fax (907) 474-6285
}

Funding for this project was provided by Saltonstall-Kennedy fishery development funds (S-K project no. 85-ABH-00046). The Alaska Sea Grant College Program is supported by the University of Alaska with state funds and by the U.S. Department of Commerce, NOAA Office of Sea Grant and Extramural Programs, grant no. NA86AA-D-SG041, project nos. A/71-01 and A/75-01. The University of Alaska is an affirmative action/ equal opportunity employer and educational institution. 